\title{
Gestational Diabetes, Colorectal Cancer, Bariatric Surgery, and Weight Loss among Diabetes Mellitus Patients: A Mini Review of the Interplay of Multispecies Probiotics
}

\author{
Emmanouil Benioudakis ${ }^{1}$, Eleni Karlafti ${ }^{1}$ (D), Alexandra Bekiaridou ${ }^{1}$ (D), Triantafyllos Didangelos ${ }^{1}$ (D) \\ and Theodossis S. Papavramidis ${ }^{2, *}$ \\ 1 1st Propaedeutic Department of Internal Medicine, Medical School, University General Hospital of \\ Thessaloniki AHEPA, Aristotle University of Thessaloniki, 54636 Thessaloniki, \\ Greece;manolis2668@hotmail.gr (E.B.); linakarlafti@hotmail.com (E.K.); ampekiaridou@gmail.com (A.B.); \\ didang@auth.gr (T.D.) \\ 2 1st Propaedeutic Surgical Department, University Hospital of Thessaloniki AHEPA, Aristotle University of \\ Thessaloniki (AUTH), 54636 Thessaloniki, Greece \\ * Correspondence: papavramidis@hotmail.com; Tel.: +30-6944536972; Fax: +30-2310420293
}

Citation: Benioudakis, E.; Karlafti, E.; Bekiaridou, A.; Didangelos, T.;

Papavramidis, T.S. Gestational

Diabetes, Colorectal Cancer, Bariatric Surgery, and Weight Loss among Diabetes Mellitus Patients: A Mini Review of the Interplay of Multispecies Probiotics. Nutrients 2022, 14, 192. https://doi.org/ $10.3390 /$ nu14010192

Academic Editor: Maria Ida Maiorino

Received: 19 November 2021 Accepted: 29 December 2021 Published: 31 December 2021

Publisher's Note: MDPI stays neutral with regard to jurisdictional claims in published maps and institutional affiliations.

Copyright: (c) 2021 by the authors Licensee MDPI, Basel, Switzerland. This article is an open access article distributed under the terms and conditions of the Creative Commons Attribution (CC BY) license (https:// creativecommons.org/licenses/by/ $4.0 /)$.

\begin{abstract}
Diabetes mellitus has been steadily increasing over the past decades and is one of the most significant global public health concerns. Diabetes mellitus patients have an increased risk of both surgical and post-surgical complications. The post-surgical risks are associated with the primary condition that led to surgery and the hyperglycaemia per se. Gut microbiota seems to contribute to glucose homeostasis and insulin resistance. It affects the metabolism through body weight and energy homeostasis, integrating the peripheral and central food intake regulatory signals. Homeostasis of gut microbiota seems to be enhanced by probiotics pre and postoperatively. The term probiotics is used to describe some species of live microorganisms that, when administered in adequate amounts, confer health benefits on the host. The role of probiotics in intestinal or microbial skin balance after abdominal or soft tissue elective surgeries on DM patients seems beneficial, as it promotes anti-inflammatory cytokine production while increasing the wound-healing process. This review article aims to present the interrelation of probiotic supplements with DM patients undergoing elective surgeries.
\end{abstract}

Keywords: probiotics; diabetes mellitus; surgical patients; wound healing; weight loss; bariatric surgery

\section{Introduction}

Diabetes mellitus (DM) has been rising rapidly in recent decades and is one of the largest global public health concerns [1,2]. The global prevalence of DM is estimated to be $9.3 \%$, projecting an increasing trend for the coming decades [1]. DM mainly consists of three types: diabetes mellitus type 2 (T2D), which accounts for approximately $90 \%$ of the total DM incidents; diabetes mellitus type 1 (T1D), which requires lifelong administration of exogenous insulin; and gestational diabetes mellitus (GDM) [1]. Uncontrolled DM creates an increased risk of serious macro- and micro-vascular complications, resulting in kidney failure, blindness, and increased mortality. It is also frequent among surgical patients, constituting a major burden for postoperative recovery.

Abdominal surgeries, major or minimal, are a wide category of surgeries that include all gastrointestinal, urological, and gynaecological operations undertaken for any indication [3]. Despite the scientific advancement of laparoscopic abdominal surgeries, they are still associated with a high rate of severe postoperative complications and long-term disability [4,5]. DM patients have an increased risk of both surgical and post-surgical complications [5]. The post-surgical risks are associated both with the primary condition that led to surgery and the hyperglycaemia itself. Hyperglycaemia may occur in both DM 
and non-DM patients due to the stress of the surgery operation and is closely associated with postoperative infections, such as wound infection, sepsis, and pneumonia [6]. The administration of probiotics has demonstrated interesting results, improving postoperative outcomes among DM patients. The term probiotics is used to describe some species of live microorganisms that, when administered in adequate amounts, confer health benefits on the host [7] due to their contribution to the intestinal microbial balance [8]. Naturally, the human gastrointestinal tract harbours a vast group of microorganisms known as "gut microbiota" [6]. The gut microbiota is a complex micro-ecosystem of billions of bacteria, fungi, viruses, and bacteriophages [6]. It seems to contribute to glucose homeostasis through bacteria involved in the control of inflammation and energy homeostasis [9] as well as through the host's metabolism [10].

The increasing global concern towards postoperative infections and the limitations of infection control strategies has led to alternative strategies. Nutritional adjuncts, such as probiotics, have emerged as potential complementary treatments [11]. The interactions between probiotics and metabolic diseases as well as the underlying mechanisms remain unclear [12]. This review aims to highlight the effects of multispecies probiotic supplements and their interplay on gestational diabetes, colorectal cancer, bariatric surgery, and weight loss among DM patients.

\section{Search Strategy}

Literature research was performed on the association of multispecies probiotics with DM. The literature research was carried out in September of 2021 on Elsevier and Medline databases: PubMed, ScienceDirect, and Scopus. Searches were carried out using the following keywords: (1) multispecies probiotics; (2) colorectal cancer, colon cancer; (3) bariatric surgery; (4) weight loss; (5) diabetes mellitus, gestational diabetes, type 1 diabetes, type 2 diabetes; and (6) surgical site infection, wound healing. These keywords were entered into the above databases using Boolean logic. The studies included had to have a doubleblind randomized design, include DM, and be written in English. Papers were excluded if only the abstract was retrieved, they were preprints, or were conference proceedings.

\section{Results and Discussion}

\subsection{Probiotics on Gestational Diabetes Mellitus}

Gestational diabetes mellitus (GDM) is a type of diabetes that is diagnosed in the second or third trimester of pregnancy [13] and remains a common and increasing complication of pregnancy [14]. Women with GDM are at risk of high blood pressure, labour induction, or unnecessary caesarean delivery $[15,16]$. In addition, GDM is associated with infant risks, such as macrosomia, respiratory distress syndrome, birth injuries, bone fractures and shoulder dystocia, jaundice, and hypoglycaemia, thus endangering the child's health [17]. Obesity is closely associated with GDM, contributing to nearly half of GDM's prevalence [18]. Obesity has become a global healthcare problem, with steadily increasing rates among women of the reproductive age [19]. Simultaneously, it remains one of the few modifiable risk factors for GDM [14]. Bariatric surgery is becoming increasingly common for the achievement of weight loss [20], while the studies suggest that reductions in body weight before pregnancy may hold the key to the prevention of GDM [21,22]. This section will present the interrelation of probiotics with weight loss and insulin sensitivity among GDM women.

Initially, Halkjae et al. [23], in a double-blind placebo-controlled study conducted among 50 obese pregnant women, showed that the administration of probiotics strains with Streptococcus thermophilus, Bifidobacterium, and Lactobacillus genera did not significantly contribute to the reduction and control of body weight. Nevertheless, probiotics appear to influence metabolism, body weight, and energy homeostasis as they integrate the peripheral and central food intake regulatory signals [24]. Furthermore, Wickens et al., in a double-blind, randomized, placebo-controlled parallel trial conducted among 423 obese pregnant women, showed that mean blood glucose levels were significantly lower 
among the participants administered Lacticaseibacillus rhamnosus as well as Lacticaseibacillus rhamnosus being associated with lower rates of GDM in women aged $\geq 35$ years [25]. The authors speculated that Lacticaseibacillus rhamnosus altered the gut microbiota composition and function, improving insulin sensitivity and inflammation in the host. [25]. Tay et al. investigated the effect Lacticaseibacillus rhamnosus had among 33 participants with preDM [26]. The probiotic supplement of Lacticaseibacillus rhamnosus, administered for 12 weeks, showed a reduction of most DM-related values, such as haemoglobin A1c and weight, compared to the baseline but not between the intervention and control group. Nevertheless, the probiotic supplement seems to improve social functioning and mental health outcomes, a finding that needs to be further explored. Finally, according to Davidson et al.'s systematic review, the administration of probiotics for preventing GDM appears to increase the risk of pre-eclampsia and may increase the risk of hypertensive disorders of pregnancy, albeit the data were heterogeneous [27]. Further research on the clear-cut benefits and risks of probiotics, especially on pregnant women, is warranted. Clinical trials of probiotics on gestational diabetes mellitus are presented in Table 1.

Table 1. Clinical trials of probiotics on gestational diabetes mellitus.

\begin{tabular}{|c|c|c|c|}
\hline Study/Ref & $\begin{array}{l}\text { Method/ } \\
\text { Timeline/ } \\
\text { Sample/ }\end{array}$ & Probiotics Used & Results \\
\hline $\begin{array}{l}\text { Halkjae et al. (2020) } \\
{[24]}\end{array}$ & $\begin{array}{c}\text { RDBPCT2 } \\
\text { capsules twice daily } \\
\text { for } 14-20 \\
\text { Weeks } \\
n=50\end{array}$ & $\begin{array}{c}\text { Streptococcus } \\
\text { thermophilus } \\
\text { Bifidobacterium } \\
\text { breve } \\
\text { Bifidobacterium } \\
\text { longum } \\
\text { Bifidobacterium } \\
\text { infantis } \\
\text { Lactobacillus } \\
\text { acidophilus } \\
\text { Lactobacillus } \\
\text { plantarum } \\
\text { Lactobacillus } \\
\text { paracasei } \\
\text { Lactobacillus } \\
\text { delbrueckii subsp. } \\
\text { bulgaricus }\end{array}$ & $\begin{array}{l}\text { slight increase in } \\
\alpha \text {-diversity in the } \\
\text { probiotic group } \\
\text { Probiotic } \\
\text { supplements } \\
\text { contributed to the } \\
\text { reduction and body } \\
\text { weight control }\end{array}$ \\
\hline $\begin{array}{l}\text { Wickens et al. (2017) } \\
\text { [26] }\end{array}$ & $\begin{array}{c}\text { RDBPCT } \\
1 \text { capsule daily for up } \\
\text { to } 12 \text { months } \\
n=423\end{array}$ & $\begin{array}{l}\text { Lactobacillus } \\
\text { rhamnosus }\end{array}$ & $\begin{array}{c}\text { Lactobacillus } \\
\text { rhamnosus was } \\
\text { associated with lower } \\
\text { rates of GDM in } \\
\text { women aged } \geq 35 \\
\text { years } \\
\text { mean blood glucose } \\
\text { levels were } \\
\text { significantly lower in } \\
\text { the probiotic group }\end{array}$ \\
\hline Tay et al. (2020) [27] & $\begin{array}{c}\text { RDBT } \\
\text { 12-week } \\
n=33\end{array}$ & $\begin{array}{l}\text { Lactobacillus } \\
\text { rhamnosus }\end{array}$ & $\begin{array}{c}\text { Probiotic } \\
\text { supplements: } \\
\text { significantly reduced } \\
\text { HbA1c and weight } \\
\text { from baseline } \\
\text { significantly } \\
\text { improved social } \\
\text { functioning and } \\
\text { mental health }\end{array}$ \\
\hline
\end{tabular}




\subsection{Probiotics Administration on DM Patients Undergoing Bariatric Surgery}

Bariatric surgery constitutes an effective treatment for morbid obesity and causes significant weight loss results [28]. It has the potential to reduce the risks of developing GDM when performed before pregnancy [29]. The most common and effective bariatric surgery procedures for reducing weight are the Roux-en-Y gastric bypass and the vertical sleeve gastrectomy. The data suggest that probiotic administration to bariatric surgery patients provides glycaemic improvements and better DM control [30].

Mokhtari et al., in their placebo-controlled, double-blind, randomized clinical trial, investigated the use of modulators of gut microbiota, such as probiotic supplements, on blood markers of endotoxin and lipid peroxidation in patients undergoing Roux-en-Y gastric bypass surgery [28]. Participants with T2D $(n=6)$ were randomly assigned to the probiotic or control croup (1:1). The initiation of the treatment was pre-operative. Each probiotic capsule contained seven species of probiotic bacteria (Streptococcus thermophilus, Lacticaseibacillus casei, Lacticaseibacillus rhamnosus, Lactobacillus acidophilus, Lactobacillus delbrueckii subsp. bulgaricus, Bifidobacterium breve, and Bifidobacterium longum), while placebo capsules contained maltodextrin. The results showed that a four-month consumption of probiotic supplements prohibited an elevation in levels of the lipopolysaccharide-binding protein (LBP) and contributed to a more significant weight loss compared to placebo consumption. When the impact on LBP was adjusted for weight loss, this effect disappeared. The measurement of LBP is considered to reflect the circulating lipopolysaccharides (LPS) status. The literature suggests that obesity is associated with increased LPS and LPB levels [31], while high levels of LPS are observed among T1D and T2D patients [32-34]. The alteration in the gut microbiome has a pivotal role in the initiation and maintenance of obesity-related inflammation. Gut microbial metabolites can trigger innate immunity, especially LPS, through a complex process that activates the pro-inflammatory cytokines [20,34]. Furthermore, probiotic bacteria have also been shown to promote anti-inflammatory cytokine production, accelerating the inflammation phase, balancing intestinal microbial composition, and regulating immune-related cytokine expression [35,36]. Thus, the influences of probiotics can explain the effects on weight loss due to alterations in the composition of gut microbiota.

Subsequently, Ramos et al., in a randomized placebo-controlled, double-blind clinical trial, investigated the use of Lactobacillus acidophilus and Bifidobacterium lactis in the early postoperative period of patients undergoing Roux-en-Y gastric bypass operation [37]. Among the participants $(n=110), 13.8 \%$ of them had a diagnosis of T2D. The observed occurrence of T2D between probiotic or control group was (1.2:1). The present study showed significant anthropometric and metabolic parameters improvements in both groups after the Roux-en-Y gastric bypass operation. In addition, a significant reduction in triglyceride levels and total cholesterol were found in the probiotic group. Probiotic supplementation causes a decrease in cholesterol through multiple and not well-known mechanisms $[37,38]$.

Subclinical chronic inflammation is a known complication of obesity that supports the development of T2D [39-41], while inflammation that occurs after bariatric surgery mitigates some of these comorbidities [42]. The levels of inflammatory biomarkers, such as Tumour Necrosis Factor $\alpha$ (TNF- $\alpha$ ), Interleukin-6 (IL6), and C-reactive protein (CRP), can change rapidly due in part to the tight regulation of cytokine production [41-43]. There are no data to support the concept that probiotics might be a valuable tool to counteract chronic inflammation in healthy older adults [44]. However, probiotic supplementations seemed to significantly affect inflammatory parameters $[30,45,46]$. Clinical trials of DM patients undergoing bariatric surgery are presented in Table 2. 
Table 2. Probiotics administration to diabetes mellitus patients undergoing bariatric surgery (clinical trials).

\begin{tabular}{|c|c|c|c|}
\hline $\begin{array}{l}\text { Study/ } \\
\text { Ref }\end{array}$ & $\begin{array}{l}\text { Method/ } \\
\text { Timeline/ } \\
\text { Sample/ }\end{array}$ & Probiotics Used & Results \\
\hline $\begin{array}{l}\text { Mokhtari et al. (2019) } \\
\text { [29] }\end{array}$ & $\begin{array}{c}\text { RDBPCT } \\
1 \text { capsule per day for } \\
4 \text { months and } 9 \\
\text { months of additional } \\
\text { follow-up } \\
n=46\end{array}$ & $\begin{array}{l}\text { Streptococcus } \\
\text { thermophilus } \\
\text { Lactobacillus casei } \\
\text { Lactobacillus } \\
\text { rhamnosus } \\
\text { Lactobacillus } \\
\text { acidophilus } \\
\text { Lactobacillus } \\
\text { bulgaricus } \\
\text { Bifidobacterium } \\
\text { breve } \\
\text { Bifidobacterium } \\
\text { longum }\end{array}$ & $\begin{array}{c}\text { Probiotics } \\
\text { supplements } \\
\text { significantly improve: } \\
\text { serum LBP } \\
\text { TNF- } \alpha \\
\text { vitamin B12 } \\
\text { vitamin D3 } \\
\text { weight loss }\end{array}$ \\
\hline $\begin{array}{c}\text { Ramos } \\
\text { et al. (2021) [38] }\end{array}$ & $\begin{array}{c}\text { RDBPCT } \\
2 \text { capsule per day for } \\
3 \text { months } \\
n=110\end{array}$ & $\begin{array}{c}\text { Lactobacillus } \\
\text { acidophilus } \\
\text { Bifidobacterium lactis }\end{array}$ & $\begin{array}{c}\text { Probiotics } \\
\text { supplements: } \\
\text { significantly decrease } \\
\text { cholesterol } \\
\text { significantly increase } \\
\text { vitamin D } \\
\text { significantly increase } \\
\text { Vitamin B12 levels }\end{array}$ \\
\hline
\end{tabular}

Abbreviations: RDBPCT, randomized double-blind placebo control trial; LBP, lipopolysaccharide-binding protein; TNF- $\alpha$, Tumour Necrosis Factor alpha.

\subsection{Colorectal Cancer, DM Comorbidity, and Probiotics}

The chronic inflammation caused by the breach of the balance barrier between beneficial and harmful bacteria in the gastrointestinal (GI) tract disrupts the intestinal homeostasis, increasing the risk of colorectal cancer (CRC) and T2D development [47]. CRC is one of the most diagnosed cancers globally [48], with an increasing number of cases in recent decades [49]. In addition, T2D was associated with an increased incidence and prevalence of CRC, as hyperglycaemia is thought to have a significant role in the proliferation and expansion of colorectal cancer cells [50]. The influence of probiotic supplements on CRC is twofold. Multiple studies have suggested that probiotics, especially Lactobacillus strains, can be used to prevent CRC. Gut microbiota directly or indirectly influences the epigenetic processes in the aetiology of $\mathrm{CRC}$, as it is associated with beneficial factor effects on glycaemic control [51-53]. The benefit of probiotic supplements in glycaemic control was described in a meta-analysis conducted by Yao et al., in which 12 randomized control trials were evaluated with a total population of 684 T2D patients [54]. The meta-analysis demonstrated that probiotic supplementation significantly reduced glucose levels and alleviated insulin resistance. Surgery remains one of the main treatments of primary or metastatic colorectal cancers, and probiotics do not constitute a possible treatment $[55,56]$.

Gut microbiota has an essential role in postoperative infectious complications [57], such as surgical site infection (SSI), which is very common after colorectal procedures [58]. The benefit of gut microbiota after colorectal cancer surgery was reported by Kotzampassi et al. [57] in a double-blind, placebo-controlled randomized study. It included 164 patients who had undergone elective, open, colonic resection with primary anastomosis. Of the participants, 25\% had comorbid T2D diagnosis and were placed in either the placebo or the probiotics perioperative treatment group (1:1.05). The probiotic supplements consisted of four probiotic strains: Lactobacillus acidophilus, Lactiplantibacillus plantarum, Bifidobacterium lactis, and Saccharomyces boulardii. The probiotic supplements, or the placebo, respectively, were first administered on the day of operation and for 14 consecutive days. The results 
showed a considerable reduction in the overall major postoperative complications and infectious complications as well as reduced hospitalization in the probiotic group. Finally, a positive correlation between the gene expression of SOCS3 with the inflammatory biomarkers was reported in the probiotic group. The mechanism of action of probiotics may be related either to earlier bowel movement, thus preventing bacterial translocation from the gut, or to modulation of the innate immune responses [57].

Zaharuddin et al. [59] described the benefits of probiotic supplements in a randomized, double-blind placebo-controlled trial. The use of a mixture of six viable probiotic supplements strains, including Lactobacillus acidophilus, Lactobacillus delbrueckii subsp. lactis, Lacticaseibacillus casei, Bifidobacterium longum, Bifidobacterium bifidum, and Bifidobacterium infantis, among post-surgical patients with colorectal cancer was investigated. Fifty-two patients were included in the study, of whom $7.6 \%$ were diagnosed with comorbidity of T2D and were placed between the probiotic supplements and the placebo group (1:1). Participants were instructed to consume the product four weeks after their surgeries, twice daily, for six months. The results showed reduced levels of pro-inflammatory cytokines in the probiotic supplements group. This result was mainly related to lactic acid strains, as evidence has revealed that this probiotic can interfere with the signalling pathways, thus affecting the level of cytokines production.

Finally, Golkhalkhali et al. [60] investigated the effect of the probiotic supplements Lactobacillus acidophilus, Lacticaseibacillus casei, Lactobacillus delbrueckii subsp. lactis, Bifidobacterium bifidum, Bifidobacterium longum, and Bifidobacterium infantis in tandem with omega-3 fatty acid supplementation on the quality of life, chemotherapy side effects, and inflammatory markers among CRC patients. The study was conducted on 140 participants who were instructed to consume the probiotic supplements or placebo for four weeks. Among the participants, $13.5 \%$ had a comorbid diagnosis of DM (the type is not specified) and were placed between the probiotic supplements and the placebo group (1.7:1). The results showed an improvement in the probiotic supplements group in the quality-of-life parameters, such as physical function, emotional functioning, nausea, vomiting, and fatigue. Furthermore, eight weeks from baseline, the inflammatory cytokine IL-6 was significantly reduced in the treatment group compared to the placebo group. Clinical trials of colorectal cancer, diabetes mellitus, and probiotics are presented in Table 3.

\subsection{Probiotic Supplements and DM Rat Models}

Animal models of human diseases allow us to examine the role of environmental and genetic factors during disease development and to develop new therapeutic strategies, albeit lacking in human disease complexity [61]. Recent research has shown that alterations in the gut microbiota because of probiotic supplements directly affect the inflammatory state in humans. Many animal-model studies that focused on DM have clearly demonstrated the beneficial effects of probiotic strains [62]. Patients with DM usually have impairment in healing due to an imbalance of the wound-healing process [63]. The wound-healing process includes haemostasis, inflammation, and proliferative and remodelling procedures [64]. DM affects one or more biological mechanisms of these processes, caused by many factors, such as hyperglycaemia, chronic inflammation, and micro- and macro-circulatory dysfunction $[64,65]$. Diabetic foot ulcers are among the most common and severe complications of DM, leading to alarming figures of amputation and disability [66]. This section will present the beneficial effect of probiotic supplements raised from animal models with DM on wound healing after surgery. 
Table 3. Colorectal cancer, diabetes mellitus comorbidity, and probiotics (clinical trials).

\begin{tabular}{|c|c|c|c|}
\hline Study/Ref & $\begin{array}{c}\text { Method/ } \\
\text { Timeline/Sample }\end{array}$ & Probiotics Used & Results \\
\hline $\begin{array}{l}\text { Kotzampassi et al. } \\
\text { (2015) [58] }\end{array}$ & $\begin{array}{c}\text { RDBPCT } \\
1 \text { capsule twice a day } \\
\text { for } 15 \text { days } \\
n=164\end{array}$ & $\begin{array}{c}\text { Lactobacillus } \\
\text { acidophilus } \\
\text { Lactobacillus } \\
\text { plantarum } \\
\text { Bifidobacterium lactis } \\
\text { Saccharomyces } \\
\text { boulardii }\end{array}$ & $\begin{array}{c}\text { Probiotic } \\
\text { supplements: } \\
\text { significantly } \\
\text { decreased the rate of } \\
\text { all postoperative } \\
\text { major complication } \\
\text { significantly reduced } \\
\text { the rate of } \\
\text { postoperative } \\
\text { pneumonia } \\
\text { significantly } \\
\text { decreased surgical } \\
\text { site infections } \\
\text { significantly } \\
\text { decreased } \\
\text { anastomotic leakage }\end{array}$ \\
\hline $\begin{array}{l}\text { Zaharuddin et al. } \\
\text { (2019) [60] }\end{array}$ & $\begin{array}{c}\text { RDBPCT } \\
1 \text { capsule twice a day } \\
\text { for } 6 \text { months } \\
n=52\end{array}$ & $\begin{array}{l}\text { Lactobacillus } \\
\text { acidophilus } \\
\text { Lactobacillus lactis } \\
\text { Lactobacillus casei } \\
\text { Bifidobacterium } \\
\text { longum } \\
\text { Bifidobacterium } \\
\text { bifidum } \\
\text { Bifidobacterium } \\
\text { infantis }\end{array}$ & $\begin{array}{c}\text { Significantly reduced } \\
\text { levels of } \\
\text { pro-inflammatory } \\
\text { cytokines: } \\
\text { TNF- } \alpha \\
\text { IL-6 } \\
\text { IL-10 } \\
\text { IL-12 } \\
\text { IL-17A } \\
\text { IL-17C } \\
\text { IL-22 } \\
\text { in the probiotic } \\
\text { supplements group. }\end{array}$ \\
\hline $\begin{array}{l}\text { Golkhalkhali et al. } \\
\text { (2017) [61] }\end{array}$ & $\begin{array}{c}\text { RDBPCT } \\
1 \text { capsule per day for } \\
4 \text { weeks } \\
n=140\end{array}$ & $\begin{array}{l}\text { Lactobacillus } \\
\text { acidophilus } \\
\text { Lactobacillus casei } \\
\text { Lactobacillus lactis } \\
\text { Bifidobacterium } \\
\text { bifidum } \\
\text { Bifidobacterium } \\
\text { longum } \\
\text { Bifidobacterium } \\
\text { infantis }\end{array}$ & $\begin{array}{c}\text { Improvement in the } \\
\text { probiotic } \\
\text { supplements group: } \\
\text { Quality-of-Life } \\
\text { parameters (physical } \\
\text { function, emotional } \\
\text { functioning, nausea, } \\
\text { vomiting and fatigue) } \\
\text { IL-6 was significantly } \\
\text { reduced }\end{array}$ \\
\hline
\end{tabular}

Abbreviations: RDBPCT, randomized double-blind placebo control trial; RDBT, randomized double-blind trial TNF- $\alpha$, Tumour Necrosis Factor alpha; IL-6, Interleukin 6; IL-10, Interleukin-10; IL-12, Interleukin-12; IL-17A, Interleukin-17A; IL-17C, Interleukin-17C; IL-22, Interleukin-22.

Campos et al. investigated the effects of probiotic supplements on skin wounds in diabetic rats [63]. The DM rats $(n=46)$ started the preoperative probiotic or placebo supplementation eight days before surgery. Probiotic supplements were administered orally within the evidence-based recommendations for humans. The supplements consisted of Lacticaseibacillus paracasei, Bifidobacterium lactis, Lacticaseibacillus rhamnosus, and Lactobacillus acidophilus. Wounds were macroscopically evaluated a few days after the surgery. The results showed improved wound healing, mature collagen deposition, neovascularization stimulation, a reduction of the inflammatory process, and improvement of glycaemic control in the probiotic supplement group. The anti-inflammatory activity in a dextran sulfate sodium (DSS)-induced colitis rat model was also shown in Dai et al.'s [67] research, with the use of Streptococcus thermophilus, Bifidobacterium longum, Bifidobacterium breve, Bifidobacterium infantis, Lactobacillus acidophilus, Lactiplantibacillus plantarum, Lacticaseibacillus 
casei, and Lactobacillus delbrueckii subsp. bulgaricus. In addition, Mohtashami et al. [68] evaluated the wound-healing potentials of probiotics on diabetic cutaneous wounds after surgery in rats $(n=27)$. Lactobacillus delbrueckii subsp. bulgaricus and Lactiplantibacillus plantarum probiotics were administered topically [68]. Probiotics have demonstrated some benefits at the skin level through oral and topical administration [68]. The results showed that during 14 days of treatment, probiotics improved the diabetic wounds as well as showing alterations in levels of inflammatory cytokines.

Rat model experiments have proved that probiotics can be beneficial in a wide range of DM physiochemical parameters. Obesity is a high-risk factor for GDM and T2D [23,28,69]. Weight reduction with probiotic supplements in rats has been studied by Okediya et al. [70]. This study, among obese rats $(n=15)$, showed that probiotic supplements Lactobacillus acidophilus and Lactiplantibacillus plantarum, when administered orally, were effective in reducing the weight of obese rats. In addition, Lactiplantibacillus plantarum was proven effective in weight loss in Yang et al.'s [71] research. In a similar vein of DM physiochemical parameters improvement was Hsieh et al.'s [12] research among 50 DM rats, orally administered Liquorilactobacillus salivarius, Lactobacillus johnsonii, Limosilactobacillus reuteri, and Bifidobacterium animalis subsp. lactis once a day for eight weeks. The results showed a significant improvement in glucose tolerance, glycaemic levels, insulin levels, and a reduction in insulin resistance, while in streptozotocin (STZ)-induced DM rats, an attenuated STZ-induced $\beta$-cell death in a dose-dependent manner was observed, with pancreatic regions remaining intact. In addition, there was a decrease in blood urea and lipid levels, including low-density lipoprotein, triglycerides, and total cholesterol. Trials of DM rats are presented in Table 4.

Table 4. Probiotic supplements and in-vivo models of DM rats.

\begin{tabular}{|c|c|c|c|}
\hline Study/Ref & $\begin{array}{c}\text { Method/ } \\
\text { Timeline/ } \\
\text { Procedure Type/Sample }\end{array}$ & Probiotics Used & Results \\
\hline Hsieh et al. (2021) [13] & $\begin{array}{c}\text { Probiotics vs control } \\
\text { Probiotics administered } \\
\text { orally once per day for } 8 \\
\text { weeks } \\
\text { Observational study } \\
n=50 \text { DM rats }\end{array}$ & $\begin{array}{l}\text { Lactobacillus salivarius } \\
\text { Lactobacillus johnsonii } \\
\text { Lactobacillus reuteri } \\
\text { Bifidobacterium } \\
\text { animalis subsp }\end{array}$ & $\begin{array}{c}\text { The probiotic } \\
\text { supplement group } \\
\text { significantly improved: } \\
\text { Glucose tolerance } \\
\text { Glycaemic levels } \\
\text { Insulin levels } \\
\text { Insulin resistance } \\
\text { (HOMA-IR) }\end{array}$ \\
\hline Campos et al. (2020) [64] & $\begin{array}{c}\text { Probiotics vs control } \\
\text { Probiotics administered } \\
\text { orally eight days before } \\
\text { surgery and for } 18 \text { days } \\
\text { total } \\
\text { Skin wound } \\
n=64 \text { DM rats }\end{array}$ & $\begin{array}{l}\text { Lactobacillus paracasei } \\
\text { Bifidobacterium lactis } \\
\text { Lactobacillus rhamnosus } \\
\text { Lactobacillus } \\
\text { acidophilus }\end{array}$ & $\begin{array}{l}\text { The probiotic } \\
\text { supplement group } \\
\text { showed: } \\
\text { Improved wound } \\
\text { healing } \\
\text { mature collagen } \\
\text { deposition } \\
\text { neovascularization } \\
\text { stimulation reduction of } \\
\text { the inflammatory } \\
\text { process improvement of } \\
\text { glycemic control }\end{array}$ \\
\hline $\begin{array}{l}\text { Mohtashami et al. (2020) } \\
\text { [70] }\end{array}$ & $\begin{array}{l}\text { Probiotics vs control/ } \\
\text { Topical administration } \\
\text { of probiotics for } 14 \text { days } \\
\text { Cutaneous wounds } \\
n=27 \text { DM rats }\end{array}$ & $\begin{array}{l}\text { Lactobacillus bulgaricus } \\
\text { Lactobacillus plantarum }\end{array}$ & $\begin{array}{c}\text { Treatment with } \\
\text { probiotics: } \\
\text { Accelerated the healing } \\
\text { process of diabetic } \\
\text { wounds } \\
\text { Modulated the } \\
\text { inflammatory cells in } \\
\text { wound sites }\end{array}$ \\
\hline
\end{tabular}

Abbreviations: DM, diabetes mellitus; HOMA-IR, Homeostatic Model Assessment for Insulin Resistance. 


\subsection{Limitations of the Current Review}

There are several limitations in our review that should be considered. Initially, the characterization of "probiotics» did not occur through the standardized methods but after the reported studies. There are a limited number of DM related studies as well as a different methodology to them. Finally, studies presented in the Chapter: 3.3. «Colorectal cancer, DM comorbidity and probiotics» included patients with comorbid DM, so the results presented in this chapter followed the main outcomes of those studies, unless otherwise reported.

\section{Conclusions}

Overall, probiotics are generally considered safe for consumption. Exceptions are women who are already pregnant, as theoretically, there are potential risks, such as preeclampsia, increased risk of hypertensive disorders of pregnancy, and a negative influence on hematologic values in infants, such as haemoglobin levels [27,72]. Results are limited and in many cases contradictory. Future research is needed to confirm the overall safety of probiotics during pregnancy. The use of probiotics appears to contribute to weight management, thus indirectly preventing the development of DM and GDM, which are closely correlated with increased body weight. Probiotics also induce improvement in physicochemical parameters and metabolic control, so they can be considered a therapeutic approach for T2D. Their effectiveness, along with diet management, can make a significant contribution to weight loss. The gut microbiota, the skin bacteria colonization, and the microbial balance through probiotic supplement administration have been proven essential for postoperative abdominal and soft tissue surgical procedures. DM has an increased risk of serious micro- and macro-vascular complications, leading to wound-healing impairment. DM patients are at greater risk of being trapped in a persistent inflammatory condition with elevated levels of pro-inflammatory cytokines. Probiotics have an essential effect on rehabilitation after surgical procedures among DM patients, as they demonstrate antiinflammatory effects.

Author Contributions: Conceptualization, E.K., T.D., and T.S.P.; methodology, E.B., A.B., and E.K.; investigation, E.B. and E.K.; resources, E.B.; data curation, E.B. and A.B.; writing-original draft preparation, E.B. and A.B.; writing—review and editing, A.B., E.K., T.D., and T.S.P.; supervision, T.S.P. and T.D.; project administration, E.K. and T.S.P.; funding acquisition, T.S.P. All authors have read and agreed to the published version of the manuscript.

Funding: This research received no external funding.

Conflicts of Interest: The authors declare no conflict of interest.

\section{References}

1. Saeedi, P.; Petersohn, I.; Salpea, P.; Malanda, B.; Karuranga, S.; Unwin, N.; Colagiuri, S.; Guariguata, L.; Motala, A.A.; Ogurtsova, K.; et al. Global and regional diabetes prevalence estimates for 2019 and projections for 2030 and 2045: Results from the International Diabetes Federation Diabetes Atlas, 9th edition. Diabetes Res. Clin. Pract. 2019, 157, 107843. [CrossRef]

2. Lin, X.; Xu, Y.; Pan, X.; Xu, J.; Ding, Y.; Sun, X.; Song, X.; Ren, Y.; Shan, P.F. Global, regional, and national burden and trend of diabetes in 195 countries and territories: An analysis from 1990 to 2025. Sci. Rep. 2020, 10, 14790. [CrossRef]

3. Sandini, M.; Pinotti, E.; Persico, I.; Picone, D.; Bellelli, G.; Gianotti, L. Systematic review and meta-analysis of frailty as a predictor of morbidity and mortality after major abdominal surgery. BJS Open 2017, 1, 128-137. [CrossRef] [PubMed]

4. Hemmerling, T.M. Pain management in abdominal surgery. Langenbecks Arch. Surg. 2018, 403, 791-803. [CrossRef]

5. Palermo, N.E.; Garg, R. Perioperative Management of Diabetes Mellitus: Novel Approaches. Curr. Diabetes Rep. 2019, 19, 14. [CrossRef] [PubMed]

6. Simha, V.; Shah, P. Perioperative Glucose Control in Patients with Diabetes Undergoing Elective Surgery. JAMA 2019, 321, 399-400. [CrossRef] [PubMed]

7. Hotel, A.C.P.; Cordoba, A. Health and nutritional properties of probiotics in food including powder milk with live lactic acid bacteria-Joint FAO/WHO expert consultation. Prevention 2001, 5, 1-10. Available online: https://www.fao.org/3/y6398e/y639 8e.pdf (accessed on 16 December 2021).

8. Tannock, G.W. A Special Fondness for Lactobacilli. Appl. Environ. Microbiol. 2004, 70, 3189-3194. [CrossRef]

9. Delzenne, N.M.; Cani, P.; Everard, A.; Neyrinck, A.M.; Bindels, L.B. Gut microorganisms as promising targets for the management of type 2 diabetes. Diabetologia 2015, 58, 2206-2217. [CrossRef] 
10. Cani, P.D.; Osto, M.; Geurts, L.; Everard, A. Involvement of gut microbiota in the development of low-grade inflammation and type 2 diabetes associated with obesity. Gut Microbes 2012, 3, 279-288. [CrossRef]

11. Chowdhury, A.H.; Adiamah, A.; Kushairi, A.; Varadhan, K.K.; Krznaric, Z.; Kulkarni, A.D.; Neal, K.R.; Lobo, D. Perioperative Probiotics or Synbiotics in Adults Undergoing Elective Abdominal Surgery: A Systematic Review and Meta-analysis of Randomized Controlled Trials. Ann. Surg. 2020, 271, 1036-1047. [CrossRef]

12. Hsieh, P.-S.; Ho, H.-H.; Tsao, S.P.; Hsieh, S.-H.; Lin, W.-Y.; Chen, J.-F.; Kuo, Y.-W.; Tsai, S.-Y.; Huang, H.-Y. Multi-strain probiotic supplement attenuates streptozotocin-induced type-2 diabetes by reducing inflammation and $\beta$-cell death in rats. PLoS ONE 2021, 16, e0251646. [CrossRef] [PubMed]

13. American Diabetes Association. 2. Classification and Diagnosis of Diabetes: Standards of Medical Care in Diabetes-2021. Diabetes Care 2021, 44 Suppl. S1, S15-S33. [CrossRef]

14. Phelan, S.; Jelalian, E.; Coustan, D.; Caughey, A.B.; Castorino, K.; Hagobian, T.; Muñoz-Christian, K.; Schaffner, A.; Shields, L.; Heaney, C.; et al. Protocol for a randomized controlled trial of pre-pregnancy lifestyle intervention to reduce recurrence of gestational diabetes: Gestational Diabetes Prevention/Prevención de la Diabetes Gestacional. Trials 2021, 22, 1-20. [CrossRef] [PubMed]

15. Okesene-Gafa, K.A.; Moore, A.E.; Jordan, V.; McCowan, L.; Crowther, C.A. Probiotic treatment for women with gestational diabetes to improve maternal and infant health and well-being. Cochrane Database Syst. Rev. 2020, 2020, CD012970. [CrossRef]

16. Pillay, J.; Donovan, L.; Guitard, S.; Zakher, B.; Korownyk, C.; Gates, M.; Gates, A.; Vandermeer, B.; Bougatsos, C.; Chou, R.; et al. Screening for Gestational Diabetes Mellitus: A Systematic Review to Update the 2014 U.S. Preventive Services Task Force Recommendation; August Report No.: 21-05273-EF-1; Agency for Healthcare Research and Quality (US): Rockville, MD, USA, 2021.

17. Kim, S.Y.; England, L.; Wilson, H.G.; Bish, C.; Satten, G.A.; Dietz, P. Percentage of Gestational Diabetes Mellitus Attributable to Overweight and Obesity. Am. J. Public Health 2010, 100, 1047-1052. [CrossRef]

18. Różańska-Walędziak, A.; Bartnik, P.; Kacperczyk-Bartnik, J.; Czajkowski, K.; Walędziak, M.; Kwiatkowski, A. Pregnancy after bariatric surgery-A narrative literature review. Videosurgery Other Miniinvasive Tech. Maloinwazyjne 2021, 16, 30-37. [CrossRef]

19. Sheiner, E.; Menes, T.S.; Silverberg, D.; Abramowicz, J.S.; Levy, I.; Katz, M.; Mazor, M.; Levy, A. Pregnancy outcome of patients with gestational diabetes mellitus following bariatric surgery. Am. J. Obstet. Gynecol. 2006, 194, 431-435. [CrossRef]

20. Dixon, J.B.; Dixon, M.E.; O’brien, P.E. Birth Outcomes in Obese Women after Laparoscopic Adjustable Gastric Banding. Obstet. Gynecol. 2005, 106, 965-972. [CrossRef]

21. Feig, D.S.; Berger, H.; Donovan, L.; Godbout, A.; Kader, T.; Keely, E.; Sanghera, R. Diabetes and Pregnancy. Can. J. Diabetes 2018, 42, S255-S282. [CrossRef]

22. Caughey, A.B. Bariatric surgery before pregnancy-Is this a solution to a big problem? N. Engl. J. Med. 2015, 372, 877-878. [CrossRef]

23. Halkjær, S.I.; de Knegt, V.E.; Lo, B.; Nilas, L.; Cortes, D.; Pedersen, A.E.; Mirsepasi-Lauridsen, H.C.; Andersen, L.O.; Nielsen, H.V.; Stensvold, C.R.; et al. Multistrain Probiotic Increases the Gut Microbiota Diversity in Obese Pregnant Women: Results from a Randomized, Double-Blind Placebo-Controlled Study. Curr. Dev. Nutr. 2020, 4, nzaa095. [CrossRef] [PubMed]

24. Kobyliak, N.; Conte, C.; Cammarota, G.; Haley, A.P.; Styriak, I.; Gaspar, L.; Fusek, J.; Rodrigo, L.; Kruzliak, P. Probiotics in prevention and treatment of obesity: A critical view. Nutr. Metab. 2016, 13, 1-13. [CrossRef] [PubMed]

25. Wickens, K.L.; Barthow, C.A.; Murphy, R.; Abels, P.R.; Maude, R.M.; Stone, P.R.; Mitchell, E.A.; Stanley, T.V.; Purdie, G.L.; Kang, J.M.; et al. Early pregnancy probiotic supplementation with Lactobacillus rhamnosus HN001 may reduce the prevalence of gestational diabetes mellitus: A randomised controlled trial. Br. J. Nutr. 2017, 117, 804-813. [CrossRef] [PubMed]

26. Tay, A.; Pringle, H.; Penning, E.; Plank, L.D.; Murphy, R. PROFAST: A Randomized Trial Assessing the Effects of Intermittent Fasting and Lacticaseibacillus rhamnosus Probiotic among People with Prediabetes. Nutrients 2020, 12, 3530. [CrossRef]

27. Barrett, H.L.; Nitert, M.D.; Conwell, L.S.; Callaway, L.K. Probiotics for preventing gestational diabetes. Cochrane Database Syst. Rev. 2021, 4, CD009951. [CrossRef]

28. Mokhtari, Z.; Karbaschian, Z.; Pazouki, A.; Kabir, A.; Hedayati, M.; Mirmiran, P.; Hekmatdoost, A. The Effects of Probiotic Supplements on Blood Markers of Endotoxin and Lipid Peroxidation in Patients Undergoing Gastric Bypass Surgery; A Randomized, Double-Blind, Placebo-Controlled, Clinical Trial with 13 Months Follow-Up. Obes. Surg. 2019, 29, 1248-1258. [CrossRef]

29. Benhalima, K.; Minschart, C.; Ceulemans, D.; Bogaerts, A.; van der Schueren, B.; Mathieu, C.; Devlieger, R. Screening and Management of Gestational Diabetes Mellitus after Bariatric Surgery. Nutrients 2018, 10, 1479. [CrossRef]

30. Bozadjieva, N.; Heppner, K.M.; Seeley, R.J. Targeting FXR and FGF19 to Treat Metabolic Diseases-Lessons Learned from Bariatric Surgery. Diabetes 2018, 67, 1720-1728. [CrossRef]

31. Pussinen, P.J.; Havulinna, A.S.; Lehto, M.; Sundvall, J.; Salomaa, V. Endotoxemia Is Associated with an Increased Risk of Incident Diabetes. Diabetes Care 2011, 34, 392-397. [CrossRef]

32. Creely, S.J.; McTernan, P.G.; Kusminski, C.M.; Fisher, F.M.; da Silva, N.F.; Khanolkar, M.; Evans, M.; Harte, A.L.; Kumar, S Lipopolysaccharide activates an innate immune system response in human adipose tissue in obesity and type 2 diabetes. Am. $J$. Physiol. Endocrinol. Metab. 2007, 292, E740-E747. [CrossRef]

33. Devaraj, S.; Jialal, I.; Yun, J.-M.; Bremer, A. Demonstration of increased toll-like receptor 2 and toll-like receptor 4 expression in monocytes of type 1 diabetes mellitus patients with microvascular complications. Metabolism 2011, 60, 256-259. [CrossRef] 
34. Stenvinkel, P.; Ketteler, M.; Johnson, R.; Lindholm, B.; Pecoits-Filho, R.; Riella, M.; Heimbürger, O.; Cederholm, T.; Girndt, M. IL-10, IL-6, and TNF- $\alpha$ : Central factors in the altered cytokine network of uremia-The good, the bad, and the ugly. Kidney Int. 2005, 67, 1216-1233. [CrossRef]

35. Arumugam, S.; Lau, C.S.; Chamberlain, R.S. Probiotics and Synbiotics Decrease Postoperative Sepsis in Elective Gastrointestinal Surgical Patients: A Meta-Analysis. J Gastrointest Surg. 2016, 20, 1123-1131. [CrossRef] [PubMed]

36. Cheng, F.-S.; Pan, D.; Chang, B.; Jiang, M.; Sang, L.-X. Probiotic mixture VSL\#3: An overview of basic and clinical studies in chronic diseases. World J. Clin. Cases 2020, 8, 1361-1384. [CrossRef] [PubMed]

37. Ramos, M.R.Z.; Carlos, L.D.O.; Wagner, N.R.F.; Felicidade, I.; da Cruz, M.R.; Taconeli, C.A.; Fernandes, R.; Filho, A.J.B.; Campos, A.C.L. Effects of Lactobacillus acidophilus NCFM and Bifidobacterium lactis Bi-07 Supplementation on Nutritional and Metabolic Parameters in the Early Postoperative Period after Roux-en-Y Gastric Bypass: A Randomized, Double-Blind, Placebo-Controlled Trial. Obes. Surg. 2021, 31, 2105-2114. [CrossRef]

38. Wang, C.; Zhang, C.; Li, S.; Yu, L.; Tian, F.; Zhao, J.; Zhang, H.; Chen, W.; Zhai, Q. Effects of Probiotic Supplementation on Dyslipidemia in Type 2 Diabetes Mellitus: A Meta-Analysis of Randomized Controlled Trials. Foods 2020, 9, 1540. [CrossRef] [PubMed]

39. Lontchi-Yimagou, E.; Sobngwi, E.; Matsha, T.E.; Kengne, A.P. Diabetes Mellitus and Inflammation. Curr. Diabetes Rep. 2013, 13, 435-444. [CrossRef] [PubMed]

40. Hafida, S.; Mirshahi, T.; Nikolajczyk, B.S. The impact of bariatric surgery on inflammation: Quenching the fire of obesity? Curr Opin. Endocrinol. Diabetes Obes. 2016, 23, 373-378. [CrossRef]

41. Franceschi, C.; Campisi, J. Chronic Inflammation (Inflammaging) and Its Potential Contribution to Age-Associated Diseases. J Gerontol. A Biol. Sci. Med. Sci. 2014, 69 (Suppl. S1), S4-S9. [CrossRef]

42. Biobaku, F.; Ghanim, H.; Monte, S.V.; Caruana, J.A.; Dandona, P. Bariatric Surgery: Remission of Inflammation, Cardiometabolic Benefits, and Common Adverse Effects. J. Endocr. Soc. 2020, 4, bvaa049. [CrossRef]

43. Sherf-Dagan, S.; Zelber-Sagi, S.; Zilberman-Schapira, G.; Webb, M.; Buch, A.; Keidar, A.; Raziel, A.; Sakran, N.; Goitein, D.; Goldenberg, N.; et al. Probiotics administration following sleeve gastrectomy surgery: A randomized double-blind trial. Int. J. Obes. 2018, 42, 147-155. [CrossRef]

44. Peladic, N.J.; Dell'Aquila, G.; Carrieri, B.; Maggio, M.; Cherubini, A.; Orlandoni, P. Potential Role of Probiotics for Inflammaging: A Narrative Review. Nutrients 2021, 13, 2919. [CrossRef] [PubMed]

45. Chand, S.K.; Singh, R.; Pendharkar, S.A.; Bharmal, S.H.; Petrov, M.S. Interplay between innate immunity and iron metabolism after acute pancreatitis. Cytokine 2018, 103, 90-98. [CrossRef]

46. Karbaschian, Z.; Mokhtari, Z.; Pazouki, A.; Kabir, A.; Hedayati, M.; Moghadam, S.S.; Mirmiran, P.; Hekmatdoost, A. Probiotic Supplementation in Morbid Obese Patients Undergoing One Anastomosis Gastric Bypass-Mini Gastric Bypass (OAGB-MGB) Surgery: A Randomized, Double-Blind, Placebo-Controlled, Clinical Trial. Obes. Surg. 2018, 28, 2874-2885. [CrossRef]

47. Jurjus, A.; Eid, A.; Al Kattar, S.; Zeenny, M.N.; Gerges-Geagea, A.; Haydar, H.; Hilal, A.; Oueidat, D.; Matar, M.; Tawilah, J.; et al. Inflammatory bowel disease, colorectal cancer and type 2 diabetes mellitus: The links. BBA Clin. 2015, 5, 16-24. [CrossRef]

48. Rossi, M.; Mirbagheri, S.S.; Keshavarzian, A.; Bishehsari, F. Nutraceuticals in colorectal cancer: A mechanistic approach. Eur. J. Pharmacol. 2018, 833, 396-402. [CrossRef]

49. Siegel, R.L.; Jakubowski, C.D.; Fedewa, S.A.; Davis, A.; Azad, N.S. Colorectal Cancer in the Young: Epidemiology, Prevention, Management. Am. Soc. Clin. Oncol. Educ. Book 2020, 40, 1-14. [CrossRef]

50. Bonagiri, P.R.; Shubrook, J.H. Review of Associations between Type 2 Diabetes and Cancer. Clin. Diabetes 2020, 38, 256-265. [CrossRef] [PubMed]

51. Chong, E.S.L. A potential role of probiotics in colorectal cancer prevention: Review of possible mechanisms of action. World J. Microbiol. Biotechnol. 2014, 30, 351-374. [CrossRef] [PubMed]

52. Kang, Y.; Pan, W.; Cai, Y. Gut microbiota and colorectal cancer: Insights into pathogenesis for novel therapeutic strategies. Z. Gastroenterol. 2017, 55, 872-880. [CrossRef]

53. Horvath, A.; Leber, B.; Feldbacher, N.; Tripolt, N.; Rainer, F.; Blesl, A.; Trieb, M.; Marsche, G.; Sourij, H.; Stadlbauer, V. Effects of a multispecies synbiotic on glucose metabolism, lipid marker, gut microbiome composition, gut permeability, and quality of life in diabesity: A randomized, double-blind, placebo-controlled pilot study. Eur. J. Nutr. 2020, 59, 2969-2983. [CrossRef] [PubMed]

54. Yao, K.; Zeng, L.; He, Q.; Wang, W.; Lei, J.; Zou, X. Effect of Probiotics on Glucose and Lipid Metabolism in Type 2 Diabetes Mellitus: A Meta-Analysis of 12 Randomized Controlled Trials. Med. Sci. Monit. 2017, 23, 3044-3053. [CrossRef] [PubMed]

55. Buccafusca, G.; Proserpio, I.; Tralongo, A.C.; Giuliano, S.R.; Tralongo, P. Early colorectal cancer: Diagnosis, treatment and survivorship care. Crit. Rev. Oncol. 2019, 136, 20-30. [CrossRef] [PubMed]

56. Kuipers, E.J.; Grady, W.M.; Lieberman, D.; Seufferlein, T.; Sung, J.J.; Boelens, P.G.; van de Velde, C.J.H.; Watanabe, T. Colorectal cancer. Nat. Rev. Dis. Primers 2015, 1, 15065. [CrossRef] [PubMed]

57. Kotzampassi, K.; Stavrou, G.; Damoraki, G.; Georgitsi, M.; Basdanis, G.; Tsaousi, G.; Giamarellos-Bourboulis, E. A Four-Probiotics Regimen Reduces Postoperative Complications After Colorectal Surgery: A Randomized, Double-Blind, Placebo-Controlled Study. World J. Surg. 2015, 39, 2776-2783. [CrossRef]

58. Komatsu, S.; Sakamoto, E.; Norimizu, S.; Shingu, Y.; Asahara, T.; Nomoto, K.; Nagino, M. Efficacy of perioperative synbiotics treatment for the prevention of surgical site infection after laparoscopic colorectal surgery: A randomized controlled trial. Surg. Today 2016, 46, 479-490. [CrossRef] 
59. Zaharuddin, L.; Mokhtar, N.M.; Nawawi, K.N.M.; Ali, R.A.R. A randomized double-blind placebo-controlled trial of probiotics in post-surgical colorectal cancer. BMC Gastroenterol. 2019, 19, 131. [CrossRef]

60. Golkhalkhali, B.; Rajandram, R.; Paliany, A.S.; Ho, G.F.; Ishak, W.Z.W.; Johari, C.S.; Chin, K.F. Strain-specific probiotic (microbial cell preparation) and omega-3 fatty acid in modulating quality of life and inflammatory markers in colorectal cancer patients: A randomized controlled trial. Asia-Pacific J. Clin. Oncol. 2018, 14, 179-191. [CrossRef]

61. Tlaskalova-Hogenova, H.; Stepankova, R.; Kozakova, H.; Hudcovic, T.; Vannucci, L.; Tuckova, L.; Rossmann, P.; Hrncir, T.; Kverka, M.; Zakostelska, Z.; et al. The role of gut microbiota (commensal bacteria) and the mucosal barrier in the pathogenesis of inflammatory and autoimmune diseases and cancer: Contribution of germ-free and gnotobiotic animal models of human diseases. Cell Mol. Immunol. 2011, 8, 110-120. [CrossRef]

62. Kootte, R.S.; Vrieze, A.; Holleman, F.; Dallinga-Thie, G.M.; Zoetendal, E.G.; de Vos, W.M.; Groen, A.K.; Hoekstra, J.B.L.; Stroes, E.S.; Nieuwdorp, M. The therapeutic potential of manipulating gut microbiota in obesity and type 2 diabetes mellitus. Diabetes Obes. Metab. 2012, 14, 112-120. [CrossRef]

63. Campos, L.F.; Tagliari, E.; Casagrande, T.A.C.; de Noronha, L.; Campos, A.C.L.; Matias, J.E.F. effects of probiotics supplementation on skin wound healing in diabetic rats. Arq. Bras. Cir. Dig. 2020, 33, e1498. [CrossRef]

64. Baltzis, D.; Eleftheriadou, I.; Veves, A. Pathogenesis and Treatment of Impaired Wound Healing in Diabetes Mellitus: New Insights. Adv. Ther. 2014, 31, 817-836. [CrossRef] [PubMed]

65. Salazar, J.J.; Ennis, W.J.; Koh, T.J. Diabetes medications: Impact on inflammation and wound healing. J. Diabetes Complicat. 2016, 30, 746-752. [CrossRef] [PubMed]

66. Rodríguez-Rodríguez, N.; Martínez-Jiménez, I.; García-Ojalvo, A.; Mendoza-Marí, Y.; Guillén-Nieto, G.; Armstrong, D.; BerlangaAcosta, J. Wound Chronicity, Impaired Immunity and Infection in Diabetic Patients. MEDICC Rev. 2021. [CrossRef]

67. Dai, C.; Zheng, C.-Q.; Meng, F.-J.; Zhou, Z.; Sang, L.-X.; Jiang, M. VSL\#3 probiotics exerts the anti-inflammatory activity via PI3k/Akt and NF-kB pathway in rat model of DSS-induced colitis. Mol. Cell. Biochem. 2013, 374, 1-11. [CrossRef] [PubMed]

68. Mohtashami, M.; Mohamadi, M.; Azimi-Nezhad, M.; Saeidi, J.; Nia, F.F.; Ghasemi, A. Lactobacillus bulgaricus and Lactobacillus plantarum improve diabetic wound healing through modulating inflammatory factors. Biotechnol. Appl. Biochem. 2021, 68, 1421-1431. [CrossRef]

69. Fontané, L.; Benaiges, D.; Goday, A.; Llauradó, G.; Pedro-Botet, J. Influence of the microbiota and probiotics in obesity. Clínica Investig. Arterioscler. 2018, 30, 271-279. [CrossRef] [PubMed]

70. Effect of Lactobacillus acidophilus and Lactobacillus plantarum on Weight Reduction in Obese Rats. Trop. J. Nat. Prod. Res. 2021, 5, 759-762. [CrossRef]

71. Yang, F.; Wang, J.; Zhang, H.; Xie, Y.; Jin, J.; Liu, H.; Pang, X.; Hao, H. Hypoglycemic effects of space-induced Lactobacillus plantarum SS18-5 on type 2 diabetes in a rat model. J. Food Biochem. 2021, 45, e13899. [CrossRef] [PubMed]

72. Baldassarre, M.E.; Palladino, V.; Amoruso, A.; Pindinelli, S.; Mastromarino, P.; Fanelli, M.; Di Mauro, A.; Laforgia, N. Rationale of Probiotic Supplementation during Pregnancy and Neonatal Period. Nutrients 2018, 10, 1693. [CrossRef] [PubMed] 